\title{
1. “糖のながれ”を見据えた治療を
}

順天堂大学医学部代謝内分泌学

河盛 隆造

本邦をはじめ世界中で, 高血圧, 高脂血症の治療の進展に より, 脳血管障害, 心疾患による死亡率は減少しつつある。 しかし糖尿病患者においては, 心脳血管イベントは增加し続 けている。そその理由は, 血糖コントロールが不十分である点 にある。経口掑取された糖質が十二指腸でブドウ糖と果糖に 変換され, 門脈から流入し全身細胞のエネルギーとして利用 されていくありさまを，演者は“糖のながれ”と名付けてい る。“糖のながれ”，その結果としての血糖応答反応を規制し ているのが，インスリン分泌動態と全身細胞のインスリン感 受性の程度にあることはいうまでもない。“糖のながれ”の いずれに乱れが生じても耐糖能障害が生じる。“糖のながれ” の正常化を目指す治療が望まれ，現実に可能であることを強 調したい.

\section{2. 糖尿病と心原性塞栓症：その関係を識る}

財団法人心臟血管研究所循環器科 山下 武志

脳血管障害の原因として, 年々心原性塞栓症が大きな位置 を占めるようになった。 現在, 脳梗塞の $30 \sim 40 \%$ が心原性塞 栓症によるものと考元られ，そのうち約半数が「心房細動」 によるものと考元られるに至っている。この心房細動は加齢 に伴い䫓著に增加するので, 今後高齢者人口が増加の一途を たどると予想される今, 心房細動の管理は重要な社会的テー マである。これまで糖尿病と心疾患の関係では, 動脈硬化に よる虚血性心疾患が注目されてきた。しかし，このような現 況では, 罹患率の高い糖尿病と心房細動の関係を改めて把握 しなければならないだろう. Framingham study では, 糖尿病 は心房細動新規発症の独立した危険因子とされる．また，心 房細動に糖尿病が合併すると, それは同時に脳塞栓症発症の 危険因子でもある。しかも，患者サイドに立ってみると，糖 疗病患者では心房細動がより無症候性となりやすいことが知 られている.このような中, すべての糖尿病患者は, 心房細 動, そして心房細動による脳梗塞の予備軍という認識を持つ 必要性が生まれている。 